\title{
Correction to: Assessment Policy and Practice of Slovenia
}

\author{
Klaudija Šterman Ivančič and Urška Štremfel
}

\section{Correction to: \\ Chapter 19 in: H. Harju-Luukkainen et al. (eds.), Monitoring Student Achievement in the 21 st Century, https://doi.org/10.1007/978-3-030-38969-7_19}

The original website of the link that was mentioned in the chapter 19 reference: Šterman Ivančič, K., \& Puklek Levpušček, M. (2018) Individual and teacher-level predictors of student achievement: PISA 2015. Presentation from EARA 2018. Ghent: European Association for Research on Adolescence has been hacked and removed as it leads to an inappropriate website.

Therefore, the link has been removed and corrected reference is listed in chapter 19 as follows:

Šterman Ivančič, K., \& Puklek Levpušček, M. (2018) Individual and teacherlevel predictors of student achievement: PISA 2015. Presentation from EARA 2018. Ghent: European Association for Research on Adolescence. 